\title{
Towards a sustainable future with education?
}

\author{
Anne-Katrin Holfelder ${ }^{1}$ (1)
}

Received: 31 August 2018 / Accepted: 8 March 2019 / Published online: 6 May 2019

(c) The Author(s) 2019

\begin{abstract}
The call for a kind of education which can contribute to a sustainable future has resulted in the "education for sustainable development" (ESD) campaign. What is implied here is that a sustainable future can be achieved if people are properly educated. ESD ignores the current, popular perception that the future is non-shapeable and determined regarding sustainability issues; ESD presupposes a necessary understanding of a future that can be formed. The logic of standard education supports the perception of a future non-shapeable through the promotion of competencies designed for flexibility. Nevertheless both systems still conceive of education mainly as training, closing down the future. In this contribution, I argue that ESD needs to take current educational systems and today's society with their non-sustainable future-building practices into account, because otherwise ESD would not make any difference to the educational and societal status quo. My main objective is to show that education must be thought of as something other than just training: considering education predominantly as subjectification holds the possibility for open and alternative futures. In this article, I discuss the potentials of this understanding (and the notion of an open future) for education with a view to sustainability. I explicitly address an interdisciplinary audience with the aim of raising awareness that education is more than training.
\end{abstract}

Keywords Environmental sustainability education · Education for sustainable development · Educational theory $\cdot$ Future education · Future perceptions

\section{Introduction: futures in education}

Education and the future are inseparably intertwined. It is impossible to think about educational matters without making references to the future. Our understanding of future determines, for example, what knowledge and which skills are considered to be important for the next generation. Regarding sustainability issues, it makes a difference whether sustainability is thought as a concrete aim which can be reached through technical innovation and efficiency, or whether it is more a normative direction which needs to be determined democratically. Futures in education determine decisions in the present and thus can be understood

Handled by David Löw Beer, Institute for Advanced Sustainability Studies, Germany.

Anne-Katrin Holfelder

anne-katrin.holfelder@iass-potsdam.de

1 Institute for Advanced Sustainability Studies, Berliner Str. 130, 14467 Potsdam, Germany as "futures for the present." If the future is the same as the present or can be predicted with any certainty, then it would seem to be not so difficult to decide what the next generation should best be equipped with. However, if the future is presumed to be uncertain, which is ultimately the case, then the necessary knowledge and skills are not that easy to determine.

Future in education is more than a mere temporal category: future is a symbol of "something better" (Milojević 2005). Future ought to (and can) always be better than the past; so in that sense it is different from the present. Future is understood as something which belongs to the next generation; they should have a better future than the present (Pfeiffer 2007). Thus, future needs to be understood as open, not determined, where one has the freedom to shape one's own future. So future in education is strongly related to freedom (Biesta 2010). This understanding became possible after Enlightenment, at a time when humanism - the notion of human freedom and progress-became the dominant perspective, and when the development of a better society was the main ideal. Education should make this ideal realizable 
through active engagement of the individual with his or her (human and non-human) environment. This means, further, that the notion of future in education is always considered as a result of human actions (Bokelmann 1969), but it is not understood as radically open, that is, shapeable in the sense to design a better future, something that would be closer to the ideal of a humane world. The future should be obliged to promote and support values such as democracy and self-determination. This ideal of a humane future should be understood as a guiding principle, one that imposes clear limitations on non-humane developments, rather than as a realistically achievable objective. Hence future, based on a humanistic understanding of education, is a guiding normative idea and less a prediction of a certain development (ibid.). Education has been considered as something which is free of any direct purpose or external will but, at the same time, clearly normative: it should help to bring society closer to an idealized humane future. Postmodern and postcolonial theories made us aware of the contingency of society and the problematic linear understanding of time and progress, as well as a teleological understanding of future (Milojević 2005). From a normative point of view, we must be aware that a teleological understanding of future is problematic in education today; however, what we should hold on to is the close connection between future and freedom (Biesta 2010), future as a symbol for shapeability, openness, change and self-determination.

On closer observation of society and educational practice, the described idealized picture of education seems difficult to maintain. Especially institutionalized education is far from being free of external influences (e.g., the educator or society's interests). The promise of a better future has been shattered because of a number of severe global crises. Future in post-modern societies has come to be understood, instead, as uncertain and contingent. But which understanding of future should serve today as the reference point for educational decisions? It would be conceivable to adhere to some desired vision of the future but also to adhere to a future forecasted from the present dominant perception of it. Those two different perceptions ${ }^{1}$ of "futures for the present" mark the parameters within which education occurs in education programs as well as in the public discourse. The future understandings give information about how education is perceived: education could be considered as a means to approach a specific end; it could also be seen as a means to respond to a given situation in the future. Neither viewpoint takes the idea of future in education seriously. In the first case, future is not understood as open and left to the next generation. Education serves rather as an instrument for attaining some specified objective. In the second case, future

\footnotetext{
1 This distinction and the following analysis of futures in education need to be understood analytically.
}

is not considered as the result of human actions, it is reduced to being just something we react to. In both cases, education is a means, a qualification which can be reached. And in both cases, the understanding of education contradicts the importance we attach to self-determination and openness.

In this contribution, I discuss the meaning of an open future for education in the context of sustainability. The importance of education as a main contributor to a sustainable future is omnipresent. I take the worldwide "education for sustainable development" campaign as an example for how education is discussed predominantly, with regard to sustainability (part II). I argue that a broader perspective on future making practices in society and institutions must be acquired. The leading question in the discourse is more often, "How can we close the knowledge-action gap?" Education in that context is often referred to as a "tool" or "remedy" which can bring about a better future if used correctly. What is missing is the integration of our current understanding of future in educational institutions (part III) and society (part IV). Our current understanding of future in present-day educational institutions and of future practices in society stands in opposition to the idealized notion of future in ESD and thus sustainability. I argue that these notions need to be explicitly addressed in designing ESD; otherwise ESD would do nothing beyond paying lip service to sustainability while continuing to foster the current non-sustainable status quo. In the final section (part V), I will discuss how education can be conceived in the context of sustainability as this pertains to an understanding of future as open. This openness is a necessary assumption when thinking about social change (Sandford 2013). I argue for an understanding of education, which considers education as more than qualification or training (for reaching a pre-defined aim). Motivated by the observation that education in public and political discussions is often regarded as a solution to non-sustainability, I want to address an interdisciplinary audience. ${ }^{2}$

\section{Education for a sustainable future}

Agenda 21 initially mentioned education as one important contribution to sustainable development. This resulted ultimately in the $\mathrm{ESD}^{3}$ campaign, initiated by UNESCO and promoted worldwide during the UN Decade of education for sustainable development beginning in 2005. Education

\footnotetext{
2 This means that I am compelled to condense and simplify some of the discussion.

${ }^{3}$ I use the term "Education for Sustainable Development" for efforts in education which refer to the political call for sustainable development. I do not integrate (often already much longer existing) educational approaches which are highly relevant with regard to sustainability. Here, I rather use "education in terms of sustainability".
} 
(mainly understood as enabling the learner to acquire certain competencies) is supposed to make a significant contribution to sustainable development. The ESD program is a highly ambitious one; it implies the hope of actually making a sustainable future:

ESD is an essential contribution to all efforts to achieve the SDGs, enabling individuals to contribute to sustainable development by promoting societal, economic and political change as well as by transforming their own behaviour. ESD can produce specific cognitive, socio-emotional and behavioural learning outcomes that enable individuals to deal with the particular challenges of each SDG, thus facilitating its achievement. In short, ESD enables all individuals to contribute to achieving the SDGs by equipping them with the knowledge and competencies they need, not only to understand what the SDGs are about, but to engage as informed citizens in bringing about the necessary transformation (UNESCO 2017).

The aim of the campaign has been to educate people so that they acquire competencies and learn to think and behave in a sustainable way. ESD is a wide-ranging project that concerns all types of education (formal and non-formal, general and specialized vocational), all disciplines, and persons of any age. It goes beyond imparting knowledge or raising awareness. Its main focus is on fostering sustainable behavior, in private and non-private contexts. In the academic milieu, the call to foster sustainable behavior was mainly answered by determining what the necessary competencies for so doing must be. Among the more important proficiencies are systems-thinking competence, anticipatory competence, normative competence, strategic competence, interpersonal competence and critical thinking (Wiek et al. 2011; Rieckmann 2013). In general, competencies are understood as a combination of cognitive skills and abilities as well as the motivational, volitional, and social readiness to solve problems responsibly in a variety of situations (cf. Weinert 2001). Consequently, competencies are not based on any specific knowledge content, but rather more oriented toward questions of how the acquisition of the required competencies can be made possible. Many scholars stress the point that innovative learning (enabling students to acquire competencies) is indispensable for ESD (e.g. Gidley 2012).

ESD clearly exceeds the goal to impart knowledge and raise awareness; it is about a variety of learning outcomes that are conceived as a contribution to societal transformation. The success of education in accordance with the logic of the political call will be determined by the extent to which sustainable development goals (SDGs) are realized. This ambitious and all-embracing objective is surprising because of the gap between knowledge, awareness, and action, something that is well-known from decades of environmental education (Kollmuss and Agyeman 2002). But the hope of creating a better future through education seems to rest on the development of more innovative and alternative methods and the focus on competencies. This "new orientation" tries to improve the negative image of environmental education which is still burdened with having an image of being indoctrination and instrumentalisation (cf. Jickling and Sterling 2017). In addition, the lack of success of environmental education is often attributed to its focus on catastrophes. According to the promoters of ESD, however, shifting this focus to competencies would be one plausible response to this criticism. The claim is that competencies combine the openness to reflect on values with one's own viewpoint in conjunction with the focus on actions. This focus on actions is further strengthened by an orientation toward a positive vision (Haan 2006).

In the academic discussion of ESD, this euphemistic promotion of a politically set program is contested: It is still criticized for reasons of instrumentalisation (Kopnina 2012; Dahlbeck 2014; Sund and Öhman 2013; Bonnett 2004). These scholars stress the point that setting a sustainable future as a clear, realistic goal in education (and, in so doing, determining exactly what constitutes sustainable action) is not the right approach. Rather, sustainable development should be considered as a process in which citizens need to take an active part. Therefore the focus of education should be on the promotion of critical thinking and reflecting (Jickling and Wals 2008; Öhman and Östman 2008). Scholars raising this criticism often refer to the continuation of the developmental paradigm in ESD, which sees development as technological progress and economic growth, and thus reproduces societal foundations that are considered to be the cause of the crisis and not as its solution (Bonnett 2004). Humans are able to control and manage crises via science and technology (Kopnina 2014); learners are addressed as consumers, reflecting a neoliberal economic understanding of the human being as one more component in a market-dominated and market-controlled society (Selby 2006). Huckle and Wals (2015) even concluded that ESD failed to challenge neoliberalism, accusing ESD of being "misplaced idealism" (ibid., p. 492). The need for the active integration of pluralistic views and alternatives is further highlighted (Kopnina 2012). The meaning and understanding of education in various ESD approaches is tightly connected to the underlying notion of (a sustainable) future: If a sustainable future is assumed to be attainable through technical innovation, efficiency and different consumer habitswhich is the case for the dominant sustainable development paradigm - the needed knowledge and skills can be defined quite precisely (cf. Kopnina 2014). Future is then something forecastable and calculable. If the concrete form of a sustainable future needs to be negotiated in society, participation 
and decision-making skills become more important aims in education.

The presented critique on ESD is based on normative arguments. I would like to expand the discussion of education in terms of sustainability by integrating structural and empirical arguments into it. So far, success or limitations are discussed mainly on the individual psychological level. ESD (like all education) is clearly a project about the future. My objective here is to draw to the special attention of my readership that a human being is socialized in particular way, depending on the society of which he or she is a part and on the particular school system in which he or she is educated, with its established future practices. It is therefore important that we have a look at how the future is perceived in current educational systems (part III) and Western developed societies (part IV). My argument is that if ESD really wants to contribute to societal transformation in the direction of sustainability, the preconditions for so doing need to be addressed and, at the same time, the limitations of education beyond the knowledge-action gap need to be recognized (part V).

\section{Education for an uncertain future}

Since at least two decades, education policies have been influenced increasingly by actors outside the traditional education system, such as the IMF, World Bank and OECD (Robertson and Dale 2009; Walker 2009). Educational systems in many OECD countries have undergone a change toward an output-orientation with a focus on competencies. With the PISA study (first conducted in 2000), the OECD defined what is regarded as important competencies ${ }^{4}$ (in mathematics, text understanding, science, and financial literacy) worldwide. In addition to subject-related competencies, the OECD also developed competencies which are considered as important for "a successful life and a well-functioning society" (Rychen and Salganik 2003). With its Definition and Selection of Competencies Program (DeSeCo), the OECD defined key competencies important for all individuals in globalized modern societies (OECD 2002). Key competencies are "acting in heterogeneous groups," "acting autonomously," and "interactive use of mediums and tools." The defined competencies are based on the following depiction of the future:

"Globalisation and modernisation are creating an increasingly diverse and interconnected world. To

\footnotetext{
${ }^{4}$ Competence in the context of PISA is defined as "the necessary prerequisites for meeting complex demands" (OECD 2001). A solely cognitive notion of competence is used here; motivational and volitional aspects (cf. Weinert 2001) are not included.
}

make sense of and function well in this world, individuals need for example to master changing technologies and to make sense of large amounts of available information. They also face collective challenges as societies-such as balancing economic growth with environmental sustainability, and prosperity with social equity. In these contexts, the competencies that individuals need to meet their goals have become more complex, requiring more than the mastery of certain narrowly defined skills" (OECD 2005, p. 4).

The leading questions for defining competencies were the following: "What do individuals need in order to function well in society as they find it; what competencies do they need to find and to hold down a job; what kind of adaptive qualities are required to cope with changing technology?" (ibid., p. 6) In this description, a clear assumption about the future is made. There seems to be no doubt the world is becoming increasingly more complex and that current problems are worsening. The future is understood as uncertain and fast-changing, which justifies the importance attached to flexibly applicable competencies. The OECD names normative issues ("democratic values and achieving sustainable development" are considered as "shared values") which are not specified in greater detail. The OECD document says that "competence is also an important factor in the ways that individuals help to shape the world, not just to cope with it" (ibid., p. 6), whereby "shaping the world" seems to be less a goal than it is a useful side effect. A clearer statement about what is desirable and what the links between agency and coping might be is missing.

On the explicit level the focus on competencies is justified for the sake of the learners; on the implicit level, justification of the selected competencies is criticized for following the neoliberal logic of the market aiming to create a flexible future worker. Education is shaped increasingly by market principles such as competitiveness and producing human capital to fulfill the needs of a global economy (Milojević 2005; Rizvi and Lingard 2009; McCarthy et al. 2009; Hursh 2010). Education has become an investment which needs to pay off, in accordance with cost-benefit considerations (Sandford 2013). Although the idea underlying PISA initially was to evaluate societal participation, the study instead sparked competition (Steffens 2007).

The task of education on this understanding is first of all to make the acquisition of defined competencies possible. This task is strongly connected to "objective" knowledge (Andreotti 2014, p. 23) not only in terms of content, but also in terms of pedagogy. Pedagogy has become increasingly evidence-based, requiring validation for certain methods (Biesta 2007). Future is understood as uncertain in the sense that it does not seem possible to shape it actively. In keeping with this understanding of future, learners are perceived as 
passive recipients of knowledge, delivered to an uncertain future. Montuori (2012) speaks of "reproductive education" because, on this understanding, the aim of education is to make students adapt rather than to allow them to create (ibid., p. 65). Milojević (2005) criticizes the failure to question whether the globalized future perceived today is "the future" (ibid., p. 64); this "taken-for-granted future" means that other visions are obscured or made invisible and their proponents silenced (ibid.). Sandford (2013) describes this neoliberal economic vision as empty one because present demands are merely extended into the future. Teaching and schooling speak more the language of competitive excellence, a practice which narrows learners' prospects and their view of the future considerably, instead of offering different possibilities (Hutchinsons 2002, p. 57). Amsler and Facer (2017) call the neoliberal and outcome-oriented shift in Western school systems as an "anticipatory regime" which stifles imagination and experimentation. On this understanding the future is not a place of possibilities, ${ }^{5}$ but rather one of foreboding, creating anxiety and necessitating control (ibid.). The future as something non-shapeable and without any alternatives is also a dominant societal perception which I will turn to in the next section.

\section{A narrowed future: empirical consideration}

In fact, humans constantly look to the future, and create mental images of what the future might be like. These self-created images emerge as hopes, fears, and expectations, and thus influence what people feel is worth doing in the present and are among the causes of present behavior (Liu and Lin 2016, p. 81).

Looking ahead to the future is inherently human; it is considered to be an important aspect of decision making and behaviour. Those "futures for the present" are of interest vis-à-vis educational concerns, and they are researched widely in the field of environmental education and ESD. But a negative image of, and pessimistic attitude toward, the societal and environmental future is almost always inherent in most of these studies conducted in western societies (e.g. Hicks 2012; Eckersley 2002). These studies stress the point that most young people are aware of (and concerned about) the environmental situation, but that they are not optimistic about change or improvement. One way to distinguish among various mental images of the future is to differentiate between expected (probable), promised (possible), and preferred (positive visions of) futures (Eckersley 2002). Based

\footnotetext{
5 The critique that the neoliberal influence forecloses future possibilities is also made explicitly for ESD and environmental education (Schindel Dimick 2015; Derby et al. 2015; Hursh et al. 2015).
}

on those categories, most studies of young people refer primarily to probable futures. Images of future society are limited to likely outcomes which follow current paths and logics, in other words, which mirror the present. Although awareness of the possibilities for change can be stated, a connection between probable futures and preferable futures is missing. The "real world" and the "ideal world" are differentiated when discussing sustainability-related topics (Zeyer and Roth 2011). Although sustainability is considered as a desirable goal, real changes to improve things are thought to be possible only in an "ideal world," that is, one in which morality constitutes the basis for actions. In the "real world," neoliberal market logic and unmitigated self-interest dominate and are thought to be unavoidable. As both worlds are disconnected from each other, there can be no hope of any improvement. The future is largely perceived as predetermined and unsustainable (Holfelder 2017). Young people often express feelings such as helplessness or hopelessness (Ojala 2017).

ESD focuses mainly on society in general and therefore more distant futures, rather than an individual's personal future-something that is likely due to the educational system's separation of disciplines. Distant futures are viewed as static images which can be described from an outside perspective (Carabelli and Lyon 2016). Such visions of the future are considered to be modified copies or a reflection of the present because they reproduce society's current problems (Eckersley 2002). Research on youth futures indicates that societal or distant future is distinguished from one's own or the near future (Cook 2015; Eckersley 2002). But it is not the case that visions of societal, economic or ecological futures do not influence individual, personal futures; there is just no linear connection between them. This also explains why young people can be pessimistic about the societal, especially the environmental, future but still be optimistic about their own (e.g. Rubin 2013; Jenkins and Pell 2006). I follow Carabelli and Lyon (2016) in arguing that it is important to discuss both futures - the distant and the near-for obtaining a more complete idea about how young people orient themselves vis-à-vis the future and its challenges. Thus I would like to point to some sociological studies regarding young people and future directions in Western societies. In contrast to the distant future, the near future is explored by reconstructing the practices of young people as they engage with it.

Future is perceived as uncertain and rapidly changing, affecting how people orientate themselves in time (Woodman 2011). Woodman (2011) found a relatively present-centered orientation to the future in his observations of young people from Australia. Concentration on the short term which is perceived as shapeable is considered as one practical way of dealing with this uncertainty. Cook (2015) describes similar findings in her overview of youth studies researching the 
individual's own future: one's own, long-term future turns out to be of significantly less interest than the immediate or short-term future. Brannen and Nilsen (2002) name three different types of future orientation among European youth. (1) The future is deferred or postponed; what counts is the present. (2) In accordance with the model of adaptability, what happens in the future depends on oneself. Future itself is not predictable; it is perceived as uncertain. Young people, mainly those in higher education, consider it their task to be prepared for the future labor market. But they do not perceive themselves as active because "their emphasis is less on mastering their routes through the labor market and more on negotiating its vagaries" (ibid., p. 527). (3) Another way of dealing with the future is to concentrate on "short-term projects" in which it is considered to be an extension of the present. This type of orientation is found more often among young people with fewer economic and social resources. Leccardi (2012) describes similar orientations. Either the young people follow the model of adaptability and flexibility ("future without a project"); or they concentrate on "shortterm projects" in which the future is considered to be an extension of the present. Social relations, security and trust (in societal institutions) seem to be important factors for planning and engaging with a longer term future (Heggli et al. 2013; Cook 2015). When the future is perceived as complex, one may be overwhelmed by too many choices; the future becomes something overpowering. Coping strategies are the avoidance of responsibility, accepting things (in the long-term future) as they are, or concentrating solely on one's own immediate future where a more positive impact is perceived (Cook 2015). What all of these studies have in common is that the future is not seen as something one acts on, but rather as something which acts upon oneself.

\section{Thinking education as more than training}

All education springs from images of the future and all education creates images of the future. Thus all education, whether intended or not, is a preparation for the future. Unless we understand the future for which we are preparing, we may do tragic damage to those we teach. Unless we understand the powerful psychological role played by images of the future in motivating - or de-motivating - the learner, we cannot effectively overhaul our schools, colleges or universities, no matter what innovations we introduce (Toffler 1974).

The quotation pleads for carefulness in taking a defined image of the future for justifying certain decisions in education. In favor of the next generation, Toffler argues for a diverse and thus open understanding of future in education because the future belongs to the succeeding generation.
One main task of education is thus to encourage and support the coming generation in shaping its own future toward the ideal of a democratic and just society.

The political call for ESD emphasizes the possibility of creating a better world through education. With this in mind, future is clearly understood to be a result of human action, that is, the promise of a certain future (a sustainable one) can be fulfilled under the condition that all people are educated in a certain way. This understanding of ESD means that education is understood as training to obtain a qualification. It follows the dominant educational paradigm in Western systems, namely, that education should equip learners with competencies which are deemed useful for a fast-changing and uncertain future. The underlying justification for this is a "taken-for-granted" 6 future which "reinforce[s] the status quo, in many cases by attempting to use education as an agency in colonizing technologically and economically deterministic futures" (Gough 1990, p. 308). Future is something which you cannot shape but which acts on you; it is a threat (Facer 2013) rather than something formable which would give individuals an alternative other than submission. The OECD selected competencies reproduce and support this currently prevalent notion of a deterministic future. The OECD's selected competencies are undoubtedly important ones, but they are not inherently tied to specific moral values. They are merely means which can be used to achieve any end. E.g., the competence to think systemically can be used in warfare but also for carbon-reduced transport systems. Referring to the future as taken-for-granted (perceived in the present as passive and non-shapeable) can only result in adaption, whereby change (or initiating it) would be not possible. In both cases-for ESD and the educational system-future is perceived as a narrowed predetermined path. And in both cases, a specific notion of educability is evoked. A picture is sketched which considers human beings as closed entities able to learn anything if just the right methods are selected. This is in line with the increasingly evidence-based understanding of education wherein the basic question is "what works" or "what is effective" and not "what is it effective for" (Biesta 2010). The belief in educability, and with it the idea of an educable identity, is reproduced when the question of how to overcome the knowledge-action gap is raised, instead of asking what is and should be the contribution of education in terms of sustainability. The presented empirical findings show that the majority of young people do consider the future as nonshapeable, a response which is considered to be passive. At most they see their own, near future as shapeable. But this idea of future is opposed to an understanding of education

\footnotetext{
${ }^{6}$ Gough distinguishes "tacit," "token" and "taken-for-granted" futures.
} 
connected to freedom (described in the introduction) and it is contrary to what is needed for socioecological transformation. Those educational approaches especially, which are motivated by the idea of social change, must be based on the notion of an open future (Sandford 2013). Without it, change is inconceivable. Thus a closed perception of the future must be one of the main tackling points for education with a view to sustainability. As long as education is seen only as a "tool" for attaining a certain future, and the success of education is measured only according to how well the promoted competencies are used, the demand for an open future is undermined.

I would like to raise awareness to the fact that education is more than just training or qualification. I consider Biesta's (2010) distinction between three overlapping domains as useful in discussing this: qualification, socialisation, and subjectification. The last domain emerged during the Enlightenment and is strongly related to the notion of freedom. ${ }^{7}$ Subjectification is understood as an active process whereby an individual becomes a subject through his or her engagement with his or her (human and non-human) environment. Subjectification, contrary to socialisation, is not the integration into pre-existing orders. In fact, it allows the individual to reflect on existing orders and power relations. Consequently education actually includes a societal dimension, although this focus is often ignored (not only by considering learning as an individual process, but also in missing the chances presented by group processes). For Biesta (2010), subjectification has the potential to bring something new into the world and to the discourse because of the general acceptance of the idea that every human being is unique. He also makes a case for democracy because, fundamentally, democracy implies plurality and difference. The condition for opening alternative futures is the freedom to think and act differently (cf. Osberg 2010), which is not given when underlying societal structures, norms, rules and logics (e.g. economic growth and competitiveness) are considered as "natural" and immutable (see "A narrowed future: empirical consideration" section). But even on this understanding, it is not enough to merely inject new or different versions of futures (Facer 2013). Facer (2013) and Osberg (2010) both plead for a qualitative shift and the integration of uncertainty of the future into educational approaches: "Taking care of the future" (Osberg 2010, p. 163) means that we should take the incalculability of the future into account, and treat it as a starting point for shapeability (Facer 2013). Even providing different visions would be a "form of denial of the unknown" (ibid., p. 161). Osberg (2010) stresses, instead, the point of

\footnotetext{
7 Biesta sees this initial idea still as closed, because there is a concrete picture of an ideal human being. Still, he considers the connection of freedom and education as valid.
}

"experience and experiment of the possibility of the impossible" (ibid., p. 163). Education especially can be one site for such experimentation. ${ }^{8}$ Unlike politics where there is pressure to act, education does not require a final decision which excludes other future possibilities. What else, if not education, can serve as the venue for such experimentation?

While politics is, in principle, totalizing, dividing, spatial (applying certain rules and not others to the future, no matter how temporary and contingent these may be), education can be in principle inventionalistic (using the interplay of otherness to arrive at new rules) (Osberg 2010, p. 164).

Before any misunderstandings arise, I do not mean that there is something wrong with education conceived and practiced as qualification. There is only something wrong when this is the only accepted understanding of it. My objective is to show the difficulties for educational theory and practice in terms of sustainability, within the logic of current systems, and to raise awareness that education must and can be conceived differently. Of course, it is questionable whether this idealized demand is possible within Western school systems or even within a society grounded on many non-sustainable patterns. But one cannot expect to bring calculable results from education deemed merely qualification; education needs to be understood more as an offering than as a technique. This brings me to the next point, namely, accepting the limits of education.

Education is increasingly understood as an evidencebased effort. This is the technocratic version of education. The "how" is the dominantly discussed question, not the "why" (Biesta 2007, 2010). Biesta (2007) claims that, despite prevailing practice, education ought not to be thought of as something similar to medical science because education is more complex than mere physical interaction; education (even in qualification-based settings) is a symbolic interaction (Biesta 2007). Thus, the uncertainty and non-causality of educational processes must be a fundamental point in devising educational processes (ibid.). Education must be grounded in the "idea of an authentic human being" (Bonnett 2017, p. 87) - a human being which is a social being and dependent on fellow human beings as well as on societal structures. Accepting learners as social beings would mean taking them seriously and attempting to comprehend their views. A resulting, sustainability-relevant question would be then, "How can education strengthen learners as human beings and support them in seeing the future as something

\footnotetext{
${ }_{8}$ Masschelein (2011) points out to the initial meaning of school which "means first of all 'free time"" (ibid., p. 102). Free time means "time of study, thought and exercise. (...) Scholè, however, is the time without destination and without aim or end." (ibid., p. 103).
} 
shapeable although it is uncertain?" rather than, "How can certain competencies for an externally determined future be acquired?" Taking learners seriously and seeing education as something beyond qualification would also mean teaching them to reflect on their own educational surroundings. In the concrete case of sustainability, this means to reflect on the situation that a normative collective goal is being promoted among young learners at school-an institution in a system where individual performance is the measure of achievement. It is questionable whether the mere promise of a theoretical possibility for change is sufficient motivation for transforming a pessimistic society. So here, one must be cognizant of the structures and the limits to education.

It is not possible to discern at present how a project such as ESD can work in the best way. This would also not be desirable because education is a prospective project and human beings are neither predictable nor absolutely controllable. Still, as an illustration, I would like to share some thoughts on how the abstract and theoretical critique could be integrated into educational practice.

To reiterate, the first point (or rather the prerequisite) for education in terms of sustainability is to take the target group seriously. Simply establishing a normative principle as an educational pretext that the future is shapeable (as is done in the case of ESD) does not take the concerns of next generation sufficiently into account (because most of them do not believe that the future is shapeable). Bonnett's notion of action competence- "being effective in the real world" (2004, p. 143) —is crucial. But this can be accomplished only through real-world projects (cf. Wiek et al. 2011). I consider current societal norms, structures and logics as one main of the reasons for precluding a shapeable-future option (see Amsler as well as Kaufmann et al. in this issue). Education in sustainability must take into account explicitly societal and institutional conditions, and address them; otherwise it will reproduce and strengthen current, non-sustainable conditions (cf. Löw Beer 2018). Of course, such underlying structures will hardly be changed by education alone (especially by institutionalized education), but at least education affords the opportunity to make learners cognizant of these structures and conditions and provides them with a platform to reflect on them. In keeping with this approach is the notion of offering different views and interpretations of the present. As a guiding idea, education should enable learners to think and imagine concepts for alternative futures (Bateman 2012; Montuori 2012; Hutchinsons 2002). This is strongly connected to historical awareness (Amsler and Facer 2017; Andreotti 2014). How we view the future depends on how we see the past and the present (Kool 2017). A clarification of the historical developments leading up to the current situation would be one contribution to encouraging belief in the possibility for change. This includes, in addition to proposing different views and interpretations of the world, demonstrating that the current form of capitalism and a neoliberal understanding of the world is not a "naturally occurring" phenomenon, but one that has been historically and culturally evolved (and thus could have been and could be different). In academics, it is widely accepted that ESD needs to present the complexity of, and a pluralistic view on, problems. Kopnina (2012) warns that an emphasis on this "pluralistic view" harbors the danger of sustaining dominant political ideologies, because mainly those who have (socioeconomic and political) power and voice will be represented. Education holds the possibility to give the voiceless a voice. This also includes consideration of different concepts of nature. But, with the shift from environmental education to ESD, alternative approaches declined (Jickling and Sterling 2017; Sauvé 1996; Kopnina 2012; Hampson 2012); the anthropocentric view became dominant, wherein nature is considered only as an exploitable resource. One could argue that acceptance of a broad demand for ESD (in all types of schools and across subjects) has only been possible with an uncontested idea of ESD, similar to the manner in which sustainable development itself is uncontested. Which brings me to my final point on the discourse within ESD. A discussion about the idea of sustainability per se is crucial: it is not enough to confine the discussion to competencies as the output of ESD, because the focus on competencies leaves the question open as to which contents are selected. Competencies such as systems thinking or critical thinking are open to different interpretations of sustainability because they are only framed by a weak idea of it. Thus the continuation of coal mining, for example, can be considered sustainable because mining is only problematic for the ecological dimension. A stronger (and more normative) understanding of sustainability would exclude coal mining from sustainable practices. Without this stronger notion of sustainability, which accepts that there are critical ecological limitations that must be addressed, the crucial potential of education is missed because, under the weaker notion, nearly every status quo can be defended as sustainable. ESD often lacks a direct reference to a sustainability concept or, respectively, sustains a problematic non-sustainable notion of society (see "Education for a sustainable future" section). Without a consensus on certain views and clear objectives, the understanding of sustainability and justice within ESD is left open to any and every interpretation. One approach to this might be to define or determine exactly which contents need to be discussed or considered in ESD. Sustainability-related abstract values such as (social and economic) justice or democracy are relatively easy to agree on. The challenge is to discuss them in terms of concrete real-world situations. Defining or determining content could be a starting 
point for initiating discourse among educators about the concretization of a sustainability concept in ESD.

\section{Conclusion}

How we understand the future influences how we think about education. The prevalent view today is that the future is uncertain and non-shapeable (in terms of societal change), a view which is supported by the decision of modern educational systems to promote flexibly applicable competencies. Standardly, education means, therefore, mainly to prepare ourselves for this contingency. In contrast, the ESD campaign promotes the idea that a sustainable future is possible if people are educated in a certain way. It assumes that people consider the societal future as shapeable, an assumption that ignores the prevailing societal perception. But ESD also follows a similar understanding of what education ought to be: namely, it is conceived as training for achieving a specific aim. In both cases, future is a closed concept; the kind of future the learners should be educated for is already prescribed and, to that extent, immutable. This implies a shortsighted view of the individual and of education itself, which misses the real potentials of education for the desired societal transformation. But if education is also conceived of as a form of subjectification, educational approaches would be oriented towards the individuals' formability and creativity. In the context of ESD this would mean to support and enable learners' self-efficacy with regards to the societal future. Subjectification-based education would also mean education as a platform for experimentation and critique (e.g., of societal conditions but also of the sustainability concept itself). Where else, if not in education, is it possible to reflect collectively on current societal conditions and to consider alternatives, without having to engage in some immediate action? Education as a platform for experimentation and critical thinking requires us to think of the future as open and, at the same time, it has the potential to open up alternative futures for us to pursue.

Open Access This article is distributed under the terms of the Creative Commons Attribution 4.0 International License (http://creativeco mmons.org/licenses/by/4.0/), which permits unrestricted use, distribution, and reproduction in any medium, provided you give appropriate credit to the original author(s) and the source, provide a link to the Creative Commons license, and indicate if changes were made.

\section{References}

Amsler S, Facer K (2017) Contesting anticipatory regimes in education: exploring alternative educational orientations to the future. Futures 94:6-14. https://doi.org/10.1016/j.futures.2017.01.001

Andreotti V (2014) Critical literacy: theories and practices in development education. Policy Pract Dev Educ Rev 14:12-32
Bateman D (2012) Transforming teachers' temporalities. Futures 44:14-23. https://doi.org/10.1016/j.futures.2011.08.003

Biesta G (2007) Why "what works" won’t work. Educ Theory 57:1-22. https://doi.org/10.1111/j.1741-5446.2006.00241.x

Biesta G (2010) Good education in an age of measurement. Routledge, London

Bokelmann H (1969) Zukunft-ein Bestimmungsmoment erzieherischen Handelns. Vierteljahrsschrift für wissenschaftliche Pädagogik 45:173

Bonnett M (2004) Retrieving nature. Education for a post-humanist age. Blackwell, Malden

Bonnett M (2017) Sustainability and human being: towards the hidden centre of authentic education. In: Jickling B, Sterling S (eds) Post-sustainability and environmental education. Palgrave Macmillan, Cham, pp 79-91

Brannen J, Nilsen A (2002) Young people's time perspectives. Sociology 36:513-537. https://doi.org/10.1177/003803850203600 3002

Carabelli G, Lyon D (2016) Young people's orientations to the future. J Youth Stud 19:1110-1127. https://doi.org/10.1080/13676 261.2016.1145641

Cook J (2015) Young adults' hopes for the long-term future. J Youth Stud 19:517-532. https://doi.org/10.1080/13676261.2015.10839 59

Dahlbeck J (2014) Hope and fear in education for sustainable development. Crit Stud Educ 55:154-169. https://doi.org/10.1080/17508 487.2013.839460

Derby M, Piersol L, Blenkinsop S (2015) Refusing to settle for pigeons and parks. Environ Educ Res 21:378-389

Eckersley R (2002) Future visions, social realities, and private lives: young people and their personal well-being. In: Gidley J, Inayatullah S (eds) Youth futures. Comparative research and transformative visions. Praeger, Westport, pp 31-41

Facer K (2013) The problem of the future and the possibilities of the present in education research. Int J Educ Res 61:135-143

Gidley J (2012) Evolution of education. From weak signals to rich imaginaries of educational futures. Futures 44:46-54

Gough N (1990) Futures in Australian education: tacit, token and taken for granted. Futures 22:298-310. https://doi.org/10.1016/00163287(90)90149-C

Haan G (2006) The BLK '21' programme in Germany. Environ Educ Res 12:19-32. https://doi.org/10.1080/13504620500526362

Hampson G (2012) Eco-logical education for the long emergency. Futures 44:71-80. https://doi.org/10.1016/j.futures.2011.08.009

Heggli G, Haukanes H, Tjomsland T (2013) Fearing the future? Young people envisioning their working lives in the Czech Republic, Norway and Tunisia. J Youth Stud 16:916-931. https://doi. org/10.1080/13676261.2013.766682

Hicks D (2012) The future only arrives when things look dangerous. Futures 44:4-13. https://doi.org/10.1016/j.futures.2011.08.002

Holfelder A-K (2017) Orientierungen von Jugendlichen zu Nachhaltigkeitsthemen. Springer, Wiesbaden

Huckle J, Wals A (2015) The UN Decade of Education for Sustainable Development: business as usual in the end. Environ Educ Res 21:491-505. https://doi.org/10.1080/13504622.2015.1011084

Hursh D (2010) The long emergency: educating for democracy and sustainability in our global crisis. In: DeLeon A, Wayne Ross E (eds) Critical theories, radical pedagogies, and social education. Sense Publishers, Rotterdam, pp 139-150

Hursh D, Henderson J, Greenwood D (2015) Environmental education in a neoliberal climate. Environ Educ Res 21:299-318. https://doi. org/10.1080/13504622.2015.1018141

Hutchinsons F (2002) Cultural mapping and our children's futures: decolonizing ways of learning and research. In: Gidley J, Inayatullah S (eds) Youth futures. Praeger, Westport, pp 53-64 
Jenkins E, Pell R (2006) "Me and the environmental challenges": a survey of English secondary school students' attitudes towards the environment. Int J Sci Educ 28:765-780. https://doi. org/10.1080/09500690500498336

Jickling B, Sterling S (2017) Post-sustainability and environmental education. In: Jickling B, Sterling S (eds) Post-sustainability and environmental education. Palgrave Macmillan, Cham, pp 1-11

Jickling B, Wals A (2008) Globalization and environmental education: looking beyond sustainable development. J Curric Stud 40:1-21. https://doi.org/10.1080/00220270701684667

Kollmuss A, Agyeman J (2002) Mind the gap: why do people act environmentally and what are the barriers to pro-environmental behavior? Environ Educ Res 8:239-260. https://doi.org/10.1080/13504 620220145401

Kool Richard (2017) If the past is a foreign country, what is the future? The necessity of understanding the past, confronting the present, and envisioning the future. In: Corcoran P, Weakland J, Wals A (eds) Envisioning futures for environmental and sustainability education. Wageningen Academic Publishers, Wageningen, pp $141-150$

Kopnina H (2012) Education for sustainable development (ESD). The turn away from 'environment' in environmental education? Environ Educ Res 18:699-717. https://doi.org/10.1080/13504 622.2012.658028

Kopnina H (2014) Future scenarios and environmental education. J Environ Educ 45:217-231. https://doi.org/10.1080/00958 964.2014.941783

Leccardi C (2012) Young people's representations of the future and the acceleration of time. A generational approach. Diskurs Kindheitsund Jugendforschung 7:59-73

Liu S-C, Lin H-S (2016) Envisioning preferred environmental futures. Exploring relationships between future-related views and environmental attitudes. Environ Educ Res 24:80-96. https://doi. org/10.1080/13504622.2016.1180504

Löw Beer D (2018) Teaching and learning ecosystem assessment and valuation. Ecol Econ 146:425-434. https://doi.org/10.1016/j.ecole con.2017.12.014

Masschelein J (2011) Experimentum Scholae: the world once more ... but not (yet) finished. Stud Philos Educ 30:529-535

McCarthy C, Pitton V, Kim S, Monje D (2009) Movement and stasis in the neoliberal reorientation of schooling. In: Apple $\mathrm{M}, \mathrm{Au} \mathrm{W}$, Gandin L (eds) International handbook of critical education. Routledge, New York, pp 36-50

Milojević I (2005) Educational futures. Routledge, Abingdon-on-Thames

Montuori A (2012) Creative Inquiry. Confronting the challenges of scholarship in the 21 st century. Futures 44:64-70. https://doi. org/10.1016/j.futures.2011.08.008

OECD (2001) Definition and selection of competencies: theoretical and conceptual foundations (DeSeCo). Background paper. http://www. oecd.org/education/skills-beyond-school/41529556.pdf, checked on 30 Aug 2018

OECD (2002) Definition and selection of competencies (DESECO): theoretical and conceptual foundations. Edited by OECD. http:// www.oecd.org/pisa/35070367.pdf, checked on 6 Feb 2016

OECD (2005) The definition and selection of key competencies. Executive summary. https://www.oecd.org/pisa/35070367.pdf. Accessed 30 Aug 2018

Öhman J, Östman L (2008) Clarifying the ethical tendency in education for sustainable development practice: a Wittgenstein-inspired approach. Can J Environ Educ 13:57-72

Ojala M (2017) Hope and anticipation in education for a sustainable future. Futures 94:76-84. https://doi.org/10.1016/j.futur es.2016.10.004

Osberg D (2010) Taking care of the future? The complex responsibility of education and politics. In: Osberg D, Biesta G (eds)
Complexity theory and the politics of education. Sense Publishers, Boston, pp 157-170

Pfeiffer U (2007) Kontinuität und Kontingenz. Klinkhardt, Bad Heilbrunn

Rieckmann M (2013) The global perspective of education for sustainable development: a European-Latin American study about key competencies for thinking and acting in the world society. Environ Educ Res 19:257-258. https://doi.org/10.1080/13504 622.2012 .697547

Rizvi F, Lingard B (2009) Globalizing education policy. Routledge, London

Robertson S, Dale R (2009) The world bank, the IMF and the possibilities of critical education. In: Apple M, Au W, Gandin L (eds) International handbook of critical education. Routledge, New York, pp 23-35

Rubin A (2013) Hidden, inconsistent, and influential. Images of the future in changing times. Futures 45:38-44. https://doi. org/10.1016/j.futures.2012.11.011

Rychen DS, Salganik LH (eds) (2003) Key competencies for a successful life and a well-functioning society. Hogrefe \& Huber, Cambridge

Sandford R (2013) Located futures: recognising place and belonging in narratives of the future. Int J Educ Res. https://doi.org/10.1016/j. ijer.2013.02.007

Sauvé L (1996) Environmental education and sustainable development: a further appraisal. Can J Environ Educ 1:7-34

Schindel Dimick A (2015) Supporting youth to develop environmental citizenship within/against a neoliberal context. Environ Educ Res 21:390-402. https://doi.org/10.1080/13504622.2014.994164

Selby D (2006) The firm and shaky ground of education for sustainable development. J Geogr Higher Educ 30:351-365. https://doi. org/10.1080/03098260600717471

Steffens G (2007) Pädagogik aus neoliberaler Perspektive. In: Bierbaum H, Euler P, Feld K, Messerschmidt A, Zitzelsberger O (eds) Nachdenken in Widersprüchen. Büchse der Pandora, Wetzlar, pp $115-125$

Sund L, Öhman J (2013) On the need to repoliticise environmental and sustainability education. Environ Educ Res 20:639-659. https:// doi.org/10.1080/13504622.2013.833585

Toffler A (1974) Learning for tomorrow. The role of the future in education. Vintage Books, New York

UNESCO (2017) Learning for sustainable development goals. http:// unesdoc.unesco.org/images/0024/002474/247444e.pdf, checked on 30 June 2018

Walker J (2009) The inclusion and construction of the worthy citizen through lifelong learning. A focus on the OECD. J Educ Policy 24:335-351. https://doi.org/10.1080/02680930802669276

Weinert FE (2001) Concept of competence: a conceptual clarification. In: Rychen DS, Sagalnik LH (eds) Definition and selection of competencies-theoretical and conceptual foundations. Hogrefe \& Huber, Kirkland, pp 45-65

Wiek A, Withycombe L, Redman C (2011) Key competencies in sustainability: a reference framework for academic program development. Sustain Sci 6:203-218

Woodman D (2011) Young people and the future. Young 19:111-128. https://doi.org/10.1177/1103308817742287

Zeyer A, Roth W-M (2011) Post-ecological discourse in the making. Public Underst Sci 22:3-48. https://doi.org/10.1177/0963662510 394949

Publisher's Note Springer Nature remains neutral with regard to jurisdictional claims in published maps and institutional affiliations. 